\title{
INSTITUSI PENGELOLA ZAKAT DALAM HUKUM POSITIF DI INDONESIA
}

\author{
Junaidi Abdullah \\ Institut Agama Islam Negeri (IAIN) Kudus \\ e-mail: abdillahrafandra@gmail.com
}

\begin{abstract}
Zakat is a property that must be set aside by a Muslim or an entity that is owned by Muslims in accordance with the provisions of religion to be given to those who are entitled to receive it. Zakat should be managed properly and professionally, so that the benefits of zakat can prosper the people and can alleviate poverty and can turn mustahik into muzakki. In Indonesia, the government has made several regulations on zakat, namely with the enactment of Law number 38 of 1999 concerning the management of Zakat and has been revised by Law No. 23 of 2011. In the Law that carries out zakat management are institutions officially recognized by the government. These institutions are $B A Z N A S$ and LAZ. The form of zakat management carried out by BAZNAS and LAZ starts from the collection, distribution, utilization and reporting.
\end{abstract}

Keywords: Zakah, Management Institution of Zakah, Positive Law

\section{Pendahuluan}

Zakat merupakan salah satu rukun Islam yang ke tiga setelah membaca syahadat dan solat serta sebelum puasa dan haji. Karena sebagai rukun maka ibadah zakat ini harus 


\section{Junaidi Abdullah}

di lakukan oleh semua umat Islam yang ada di dunia karena sebagai sebuah kewajiban.

Kewajiban membayar zakat secara hukum berdasaran Al-Quran surat At-Taubah ayat 103 yang artinya: "Ambillah zakat dari sebagian harta mereka, dengan zakat itu kamu membersihkan dan mensucikan mereka, dan mendoalah untuk mereka. Sesungguhnya doa kamu itu (menjadi) ketenteraman jiwa bagi mereka. Dan Allah maha Mendengar lagi maha Mengetahui". (QS. At-Taubah: 103)

Menurut Undang-Undang nomor 38 tahun 1999 tentang Pengelolaan Zakat, yang dinamakan zakat adalah harta yang wajib disisihkan oleh seorang muslim atau badan yang dimiliki oleh orang muslim sesuai dengan ketentuan agama untuk diberikan kepada yang berhak menerimanya.

Zakat merupakan kategori ibadah wajib dan ibadah sosial. Dikatakana ibadah wajib karena ibadah zakat sama seperti ibadah solat, haji, dan puasa yang telah diatur dalam Alquran dan Sunah. Dikatakan sebagai ibadah sosial, karena zakat merupakan amal sosial kemasyarakatan dan kemanusiaan yang dapat berkembang sesuai dengan perkembangan umat manusia (Ahmad Hadi Tasin, 2012: 12).

Sebagai ibadah social diharapkan zakat mampu mengentaskan kemiskinan umat Islam, sehingga akan mengurangi kesenjangan social di salam masyarakat. Pengurangan kemiskinan ini bisa terjadi apabila seorang Mustahik berubah menjadi Muzakki (dari yang berhak mendapatkan zakat berubah menjadi seorang yang berkewajiban membayar zakat).

Namun peralihan itu mustahil terjadi apabila pengelolan zakat tidak dikelola dengan baik dan professional. Maka pengelolaan zakat itu harus dilakukan dengan tanggungjawab dan dedikasi yang tinggi untuk kemaslahatan umat. Di samping dikelola dengan 


\section{Institusi Pengelola Zakat dalam Hukum...}

professional dan bertanggungjawab, seharusnya bentuk zakat konsumtif dirubah menjadi zakat produktif.

Dalam rangka meningkatkan daya guna dan hasil guna, zakat harus dikelola secara melembaga sesuai dengan syariat Islam, amanah, kemanfaatan, keadilan, kepastian hukum, terintegrasi, dan akuntabilitas sehingga dapat meningkatkan efektivitas dan efisiensi pelayanan dalam pengelolaan zakat.

Di Indonesia, pemerintah telah membuat beberapa regulasi tentang zakat yakni dengan di berlakukannya Undang-Undang nomor 38 tahun 1999 tentang penegelolaan Zakat dan telah direvisi dengan Undang Undang nomor 23 tahun 2011. Di dalam Undang-Ungang tersebut yang melakukan pengelolaan zakat adalah institusi-institusi resmi yang diakui oleh pemerintah. Institusi-institusi tersebut adalah BAZNAS dan LAZ.

\section{Pembahasan}

\section{Konsep Zakat}

Zakat merupakan pranata sisial yang diyakini dapat mengentaskan kemiskinan dan bisa mensejahterakan masyarakat adalah kewajiban umat Islam yang harus dilaksanakan.

Secara bahasa zakat bisa berasal dari kata al-barakatu yang diartikan dengan keberkahan, bisa juga berasal dari kata ath-thaharatu yang memiliki arti kesucian, bisa juga berasal dari kata al-namaa yang mempunyai arti pertumbuhan dan perkembangan, dan bisa berasal dari kata ash-shalahu yang memiliki arti keberesan (Didin Hafhiduddin, 2002: 7).

Sedangkan zakat menurut Imam mazhab yang dikutip dalam bukunya Nuruddin Mhd. Ali, mazhab Maliki 


\section{Junaidi Abdullah}

mendefenisikan zakat dengan mengeluarkan sebagian dari harta yang khusus yang telah mencapai nishab (batas kuantitas minimal yang mewajibkan zakat) kepada orangorang yang berhak menerimanya. Mazhab Hanafi mendefenisikan zakat dengan menjadikan sebagian harta yang khusus dari harta yang khusus sebagai milik orang yang khusus, yang ditentukan oleh syariat karena Allah. Menurut mazhab Syafi'i, zakat adalah sebuah ungkapan keluarnya harta atau tubuh sesuai dengan cara khusus. Sedangkan menurut mazhab Hanbali, zakat ialah hak yang wajib dikeluarkan dari harta yang khusus untuk kelompok yang khusus pula, yaitu kelompok yang diisyaratkan dalam Alquran (Nuruddin Mhd. Ali, 2006: 6-7).

Menurut Undang-Undang nomor 38 tahun 1999 tentang Pengelolaan Zakat, yang dinamakan zakat adalah harta yang wajib disisihkan oleh seorang muslim atau badan yang dimiliki oleh orang muslim sesuai dengan ketentuan agama untuk diberikan kepada yang berhak menerimanya.

Sedangkan menurut Undang-Undang nomor 23 tahun 2011 tentang Pengelolaan Zakat, yang dimaksud dengan zakat adalah harta yang wajib dikeluarkan oleh seorang muslim atau badan usaha untuk diberikan kepada yang berhak menerimanya sesuai dengan syariat Islam.

Dari beberapa pengertian di atas dapat disimpulkan yang dimaksud dengan zakat adalah mengeluarkan sebagian harta benda yang menjadi hak miliknya dan diberikan kepada orang yang berhak menerimanya.

Maka berdasarkan Alquran bahwa tujuan zakat adalah untuk mensucikan jiwa dan untuk membersihkan harta benda dari hal-hal yang haram. Sehingga harta itu menjadi berkah dan berkembang. 


\section{Institusi Pengelola Zakat dalam Hukum...}

\section{Penggolongan zakat}

Zakat sebagai sebuah kewajiban, di dalam UndangUndang nomor 23 tahun 2011 terdiri dari: Pertama, Zakat Mal, yaitu bagian harta yang disisihkan oleh seorang muslim atau badan yang dimiliki oleh orang muslim sesuai dengan ketentuan agama untuk diberikan kepada yang berhak menerimanya. Zakat mal meliputi: (a). emas, perak, dan logam mulia lainnya; (b). uang dan surat berharga lainnya; (c). perniagaan; (d). pertanian, perkebunan, dan kehutanan; (e). peternakan dan perikanan; (f). pertambangan; (g). perindustrian; (h). pendapatan dan jasa; (i). rikaz.

Kedua, Zakat fitrah, yaitu sejumlah bahan makanan pokok yang dikeluarkan pada bulan Ramadhan oleh setiap orang muslim bagi dirinya dan bagi orang yang ditanggungnya yang memiliki kelebihan makanan untuk sehari pada hari raya Idul Fitri.

\section{Golongan yang berhak dan haram mendapatkan zakat}

Di dalam Alquran surat At-Taubah ayat 60 Allah berfirman yang artinya: "Sesungguhnya zakat-zakat itu, hanyalah untuk orang-orang fakir, orang-orang miskin, penguruspengurus zakat, para mu'allaf yang dibujuk hatinya, untuk (memerdekakan) budak, orang-orang yang berhutang, untuk jalan Allah dan untuk mereka yuang sedang dalam perjalanan, sebagai suatu ketetapan yang diwajibkan Allah, dan Allah Maha Mengetahui lagi Maha Bijaksana." (QS. At-Taubah: 60).

Dari ayat tersebut sudah jelas disebutkan bahwa yang berhak menerima zakat terdiri dari 8 golongan, yakni: golongan fakir, miskin, amil, muallaf, riqab, gharim, fi sabilillah, dan Ibnu Sabil. Sedangkan golongan yang tidak berhak mendapatkan zakat meliputi: Golongan non muslim, orang kaya, ahlul bait, dan orang yang masih menjadi tanggungjawab Muzakki (Ahmad Hadi Tasin, 2012: 12). 


\section{Junaidi Abdullah}

\section{Institusi-institusi pengelola zakat}

Supaya zakat bisa dimaksimalkan untuk kesejahteraan umat, maka zakat harus dikelola dengan baik dan professional. Yang dimaksud dengan pengelolaan zakat adalah kegiatan perencanaan, pelaksanaan dan pengawasan terhadap pengumpulan dan pendistribusian serta pendayagunaan zakat (Undang-undang nomor 23 tahun 2011 tentang Pengelolaan Zakat).

Pengelolaan zakat berasaskan: (a). syariat Islam; (b). amanah (pengelola zakat harus dapat dipercaya); (c). kemanfaatan (pengelolaan zakat dilakukan untuk memberikan manfaat yang sebesarbesarnya bagi mustahik); (d). keadilan (pengelolaan zakat dalam pendistribusiannya dilakukan secara adil); (e). kepastian hukum (dalam pengelolaan zakat terdapat jaminan kepastian hukum bagi mustahik dan muzaki); (f). terintegrasi (pengelolaan zakat dilaksanakan secara hierarkis dalam upaya meningkatkan pengumpulan, pendistribusian, dan pendayagunaan zakat); (g). akuntabilitas (pengelolaan zakat dapat dipertanggungjawabkan dan diakses oleh masyarakat.

Menurut hukum Islam dan peraturan yang berlaku di Indonesia tugas pengelolaan zakat dilaksanakan oleh Amil. Amil zakat adalah orang yang diangkat penguasa atau wakilnya untuk mengurus zakat. Tugasnya melipu penghimpunan, pengelolaan, dan pendistribusian zakat.

Menurut Yusuf Qardhawi, dengan adanya amil ini akan memberi manfaat atau keuntungan:

1. Menjamin kepastian dan disiplin pembayaran zakat

2. Menjaga perasaan rendah diri pada mustahiq zakat

3. Untuk mencapai efisiensi dan efektifitas serta sasaran yang tepat dalam penggunaan harta zakat menurut skala prioritas yang ada pada suatu tempat 


\section{Institusi Pengelola Zakat dalam Hukum...}

4. Memperlihatkan syi'ar Islam dalam semangat penyelenggaraan pemerintahan yang Islami (Yusuf Qardhawi, 1987: 43).

Amil di Indonesia yang berbentuk lembaga bisa dilakukan oleh pemerintah melalui BAZNAS (Badan Amil Zakat Nasional) maupun masyarakat melalui LAZ (Lembaga Amil Zakat).

\section{Badan Amil Zakat Nasional (BAZNAS)}

Untuk mengelola zakat, pemerintah membentuk organisasi amil yang bernama BAZNAS. Menurut Undang Undang nomor 23 tahun 2011 tentang Pengelolaan Zakat yang dimaksud dengan Badan Amil Zakat Nasional yang selanjutnya disebut BAZNAS adalah lembaga yang melakukan pengelolaan zakat secara nasional.

BAZNAS bisa berkedudukan di pusat, propinsi maupun kabupaten/kota. BAZNAS pusat diangkat oleh presiden atas usul menteri, sedangkan BAZNAS propinsi dibentuk dan diangkat oleh menteri atas usul gubernur kemudian BAZNAS kabupaten atau kota dibentuk dan diangkat oleh menteri atas saran dan usul bupati/wali kota (Peraturan Pemerintah nomor 14 tahun 2014 tentang Pelaksanaan Undang Undang nomor 23 tahun 2011 tentang Pengelolaan Zakat).

Tugas utama dari BAZNAS adalah melakukan pengelolaan zakat secara nasional. Dalam menjalankan tugas utamanya, BAZNAS mempunyai beberapa fungsi: (a). perencanaan pengumpulan, pendistribusian, dan pendayagunaan zakat; (b). pelaksanaan pengumpulan, pendistribusian, dan pendayagunaan zakat; (c). pengendalian pengumpulan, pendistribusian, dan pendayagunaan zakat; (d). pelaporan dan pertanggungjawaban pelaksanaan Pengelolaan Zakat 


\section{Junaidi Abdullah}

(Undang-Undang No. 23 Tahun 2011 tentang Pengelolaan Zakat).

Dalam menjalankan tugas dan fungsinya, BAZNAS, BAZNAS propinsi, BAZNAS kabupaten/kota bisa membentuk UPZ (Unit Pengumpul Zakat) yang mempunyai tugas mengumpulkan zakat dan menyetorkannya ke BAZNAS, BAZNAS propinsi, BAZNAS kabupaten/kota.

Pengumpulan zakat oleh BAZNAZ pusat melalui UPZ dilakukan dengan cara membentuk UPZ pada: (a). lembaga Negara; (b). kementerian/lembaga pemerintah non kementerian; (c). badan usaha milik Negara; (d). perusahaan swasta nasional dan asing; (e). perwakilan Republik Indonesia di luar negeri; (f). kantor-kantor perwakilan negara asing/lembaga asing; (g). masjid negara.

Pengumpulan zakat oleh BAZNAZ propinsi melalui UPZ dilakukan dengan cara membentuk UPZ pada: (a). kantor instansi vertical; (b). kantor satuan kerja perangkat daerah/lembaga daerah provinsi; (c). badan usaha milik daerah provinsi; (d). perusahaan swasta skala provinsi; (e). perguruan tinggi; (f). masjid raya.

Pengumpulan zakat oleh BAZNAZ kabupaten? kota melalui UPZ dilakukan dengan cara membentuk UPZ pada: (a). kantor satuan kerja pemerintah daerah/lembaga daerah kabupaten/kota; (b). kantor instansi vertikal tingkat kabupaten/kota; (c). badan usaha milik daerah kabupaten/kota; (d). perusahaan swasta skala kabupaten/kota; $€$. masjid, mushalla, langgar, surau atau nama lainnya; (f). sekolah/madrasah dan lembaga pendidikan lain; (g). kecamatan atau nama lainnya; (h). desa/kelurahan atau nama lainnya (PP no. 14 tahun 2014 tentang Pelaksanaan UU no. 23 Tahun 2011 tentang Pengelolaan Zakat). 


\section{Institusi Pengelola Zakat dalam Hukum...}

\section{Lembaga Amil Zakat (LAZ)}

Lembaga Amil Zakat (LAZ) adalah lembaga yang dibentuk masyarakat yang memiliki tugas membantu pengumpulan, pendistribusian, dan pendayagunaan zakat (Undang Undang nomor 23 tahun 2011 tentang Pengelolaan Zakat).

Pembentukan LAZ wajib mendapat izin menteri atau pejabat yang ditunjuk oleh menteri setelah memenuhi persyaratan:

a. Terdaftar sebagai organisasi kemasyarakatan Islam yang mengelola bidang pendidikan, dakwah, dan sosial, atau lembaga berbadan hukum (maksudnya adalah organisasi kemasyarakatan Islam yang mengelola bidang pendidikan, dakwah, dan sosial yang terdaftar di kementerian yang menyelenggarakan urusan pemerintahan di bidang dalam negeri atau lembaga berbadan hukum yang berbentuk yayasan atau perkumpulan berbasis Islam yang telah disahkan oleh menteri yang menyelenggarakan urusan pemerintahan di bidang hukum dan hak asasi manusia).

b. Mendapat rekomendasi dari BAZNAS

c. Memiliki pengawas syariat (maksudnya adalah LAZ memiliki pengawas syariat internal sendiri atau menunjuk pengawas syariat eksternal dari luar LAZ)

d. Memiliki kemampuan teknis, administratif, dan keuangan untuk melaksanakan kegiatannya

e. Bersifat nirlaba

f. Memiliki program untuk mendayagunakan zakat bagi kesejahteraan umat; 


\section{Junaidi Abdullah}

g. Bersedia diaudit syariat dan keuangan secara berkala. (Pasal 58 PP No. 14 Tahun 2014 tentang Pelaksanaan UU No. 23 Tahun 2011 tentang Pengelolaan Zakat).

Izin pembentukan LAZ yang diajukan oleh organisasi kemasyarakatan Islam berskala nasional diberikan oleh menteri. Sedangkan izin pembentukan LAZ yang diajukan oleh organisasi kemasyarakatan Islam berskala propinsi diberikan oleh direktur jenderal yang mempunyai tugas dan fungsi di bidang zakat pada kementerian yang menyelenggarakan urusan pemerintahan di bidang agama. Kemudian izin pembentukan LAZ yang diajukan oleh organisasi kemasyarakatan Islam berskala kabupaten/kota diberikan oleh kepala kantor wilayah kementerian agama propinsi.

LAZ dalam menjalankan pengelolaan zakat dapat membentuk perwakilan-perwakilan di daerah. Pembentukan perwakilan-perwakilan tersebut melalui mekanisme sebagai berikut:

1. LAZ berskala nasional diperbolehkan membuka perwakilan. Perwakilan tersebut hanya bisa dilakukan di setiap propinsi untuk 1 (satu) perwakilan, dan harus mendapat izin dari kepala kantor wilayah kementerian agama propinsi. Izin pembukaan perwakilan LAZ dilakukan dengan mengajukan permohonan tertulis. Permohonan tertulis diajukan oleh pimpinan LAZ kepada kepala kantor wilayah kementerian agama provinsi dengan melampirkan: (a). izin pembentukan LAZ dari menteri; (b). rekomendasi dari BAZNAS provinsi; (c). data muzaki dan mustahik; (d). program pendayagunaan zakat bagi kesejahteraan umat.

2. LAZ berskala propinsi hanya dapat membuka 1 (satu) perwakilan di setiap kabupaten/kota. Pembukaan perwakilan LAZ harus mendapat izin dari kepala kantor kementerian agama kabupaten/kota. Izin pembukaan 


\section{Institusi Pengelola Zakat dalam Hukum...}

perwakilan LAZ berskala provinsi dilakukan dengan mengajukan permohonan tertulis. Permohonan tertulis diajukan oleh pimpinan LAZ kepada kepala kantor kementerian agama kabupaten/kota dengan melampirkan: (a). izin pembentukan LAZ dari direktur jenderal yang mempunyai tugas dan fungsi di bidang zakat pada kementerian yang menyelenggarakan urusan pemerintahan di bidang agama; (b). rekomendasi dari BAZNAS kabupaten/kota; (c). data muzaki dan mustahik; (d). program pendayagunaan zakat bagi kesejahteraan umat. (PP No. 14 tahun 2014 tentang Pelaksanaan UU No. 23 tahun 2011 tentang Pengelolaan Zakat).

\section{Mekanisme pengelolaan zakat oleh BAZNAS dan LAZ}

Sebagai institusi yang mempunyai tugas utama pengelolaan zakat, maka BAZNAS dan LAZ bisa melakukan hal-hal sebagai berikut:

Pertama, Pengumpulan zakat; Dalam pengumpulan zakat ini, muzakki bisa menghitung sendiri zakatnya. Apabila tidak bisa, maka BAZNAS atau LAZ bisa membantu untuk menghitungkan zakatnya. Zakat yang sudah dibayarkan harus dikurangkan dari penghasilan kena pajak. BAZNAS naupun LAZ harus membuat bukti setoran zakat kepada muzakki sebagai buktu untuk pengurangan pajak.

Kedua, Pendistribuan zakat; Pendistribuan harta zakat harus diserahkan kepada mustahik. Pendistribusian zakat oleh BAZNAS maupun LAZ dilakukan berdasarkan skala prioritas dengan memperhatikan prinsip pemerataan, keadilan dan kewilayahan.

Ketiga, Pendayagunaan zakat; Pendayagunaan harta zakat yang dilakukan oleh BAZNAS dan LAZ seharusnya melalui usaha produktif untuk meningkatkan kesejahteraan 


\section{Junaidi Abdullah}

para mustahik lebih-lebih fakir miskin. Sehingga dengan model produktif ini bisa mengentaskan kemiskinan. Tapi yang perlu diingat, zakat untuk usaha produktif ini dapat dilakukan apabila kebutuhan dasar fakir dan miskin sudah terpenuhi.

Keempat, Pelaporan zakat; Dalam pelaksanaan pengelolaan zakat, BAZNAS maupun LAZ wajib melaporkan semua kegiatannya. Untuk BAZNAS kabupaten/kota wajib menyampaikan laporan pelaksanaan pengelolaan zakat kepada BAZNAS propinsi dan pemerintah daerah secara berkala. Sedangkan BAZNAS propinsi wajib menyampaikan laporan pelaksanaan pengelolaan zakat kepada BAZNAS dan pemerintah daerah secara berkala (UU No. 23 tahun 2011 tentang Pengelolaan Zakat)

LAZ wajib menyampaikan laporan pelaksanaan pengelolaan zakat, infak, sedekah, dan dana sosial keagamaan lainnya kepada BAZNAS dan pemerintah daerah setiap 6 (enam) bulan dan akhir tahun.

Perwakilan LAZ wajib menyampaikan laporan pelaksanaan pengelolaan zakat, infak, sedekah, dan dana social keagamaan lainnya kepada LAZ dengan menyampaikan tembusan kepada pemerintah daerah dan kepala kantor wilayah kementerian agama provinsi dan kepala kantor kementerian agama kabupaten/kota.

Laporan pelaksanaan pengelolaan zakat, infak, sedekah, dan dana sosial keagamaan lainnya harus di audit syariat dan keuangan. Audit syariat dilakukan oleh kementerian yang menyelenggarakan urusan pemerintahan di bidang agama. Sedangkan audit keuangan dilakukan oleh akuntan publik.

Laporan pelaksanaan pengelolaan zakat, infak, sedekah, dan dana sosial keagamaan lainnya yang telah di 
audit syariat dan keuangan disampaikan kepada BAZNAS. Laporan memuat akuntabilitas dan kinerja pelaksanaan pengelolaan zakat, infak, sedekah, dan dana sosial keagamaan lainnya (PP No. 14 tahun 2014 tentang Pelaksanaan UU No. 23 tahun 2011 tentang Pengelolaan Zakat).

\section{Sanksi-sanksi bagi BAZNAZ dan LAZ yang melanggar}

BAZNAS dan LAZ akan dikenai sanksi apabila melanggar dalam pengelolaan zakat. Bentuk sanksinya adalah sanksi administrasif, sanksi ini diberikan apabila: (a). tidak memberikan bukti setoran zakat kepada setiap muzaki; (b). melakukan pendistribusian dan pendayagunaan infak, sedekah, dan dana sosial keagamaan lainnya tidak sesuai dengan syariat Islam dan tidak dilakukan sesuai dengan peruntukan yang diikrarkan oleh pemberi; dan (c). tidak melakukan pencatatan dalam pembukuan tersendiri terhadap pengelolaan infak, sedekah, dan dana sosial keagamaan lainnya.

Bentuk-bentuk sanksi administrative yang diberikan kepada BAZNAS dan LAZ, berupa: (a). peringatan tertulis; (b). penghentian sementara dari kegiatan; dan (c). pencabutan izin operasional.

Sanksi administratif berupa peringatan tertulis yang dikenakan kepada BAZNAS dan LAZ apabila tidak memberikan bukti setoran zakat kepada muzakki, melakukan pendistribusian dan pendayagunaan yang tidak sesuai dengan syariat Islam, tidak melakukan pembukuan tersendiri dan tidak membuat pelaporan. Pemberian sanksi tertulis ini wewenangnya menteri untuk BAZNAS pusat. Sedangkan pemberian sanksi tertulis untuk BAZNAS dan LAZ propinsi atau kabupaten/kota adalah wewenang dari BAZNAS pusat. 


\section{Junaidi Abdullah}

Pemberian sanksi penghentian sementara dari kegiatan akan dikenakan kepada BAZNAS dan LAZ apabila mengulangi pelanggaran tidak memberikan bukti setoran zakat kepada muzakki, melakukan pendistribusian dan pendayagunaan yang tidak sesuai dengan syariat Islam, tidak melakukan pembukuan tersendiri dan tidak membuat pelaporan. Dan sanksi penghentian sementara dari kegiatan dicabut apabila BAZNAS dan LAZ telah melaksanakan ketentuan-ketentuan seperti memberikan bukti setoran zakat kepada muzakki, melakukan pendistribusian dan pendayagunaan sesuai dengan syariat Islam, melakukan pembukuan tersendiri dan membuat pelaporan. Yang berwenang meemberikan sanksi penghentian sementara dari kegiatan adalah menteri.

Sanksi berupa pencabutan ijin operasional dilakukan apabila LAZ mengulangi lagi tidak memberikan bukti setoran zakat kepada muzakki, melakukan pendistribusian dan pendayagunaan yang tidak sesuai dengan syariat Islam, tidak melakukan pembukuan tersendiri dan tidak membuat pelaporan setelah mendapatkan sanksi penghentian sementara dari kegiatan dan sanksinya telah dicabut. Sedangkan bagi BAZNAS yang melakukan pelanggaran yang kedua kalinya anggota atau pimpinan BAZNAS dianggap telah melakukan perbuatan tercela, sehingga akan mendapatkan penghentian dari jabatannya. Pemberi sanksi pencabutan ijin operasional adalah wewenang menteri (PP No. 14 tahun 2014 tentang Pelaksanaan UU No. 23 tahun 2011 tentang Pengelolaan Zakat).

\section{Simpulan}

Dari penjelasan dan uraian di atas, maka kajian ini dapat menyimpulkan bahwa institusi pengelolaan zakat menurut hukum positif di Indonesia adalah melaui badan atau lembaga yang dibentuk oleh pemerintah seperti 


\section{Institusi Pengelola Zakat dalam Hukum...}

BAZNAS dan juga bisa melalui badan atau lembaga yang dibentuk oleh masyarakat seperti LAZ.

Bentuk pengelolaan zakat yang dilakukan oleh BAZNAS dan LAZ dimulai dari pengumpulan, pendistribusian, pendayagunaan dan pelaporan. Semua rangkaian kegiatan tersebut harus dilakukan sesuai dengan regulasi yang telah ditetapkan sehingga lembaga-lembaga zakat tersebut dapat memberikan manfaat kepada masyarakat yang membutuhkan, baik dari pihak muzakki maupun mustahik.

\section{Daftar Pustaka}

Ahmad Hadi Yasin, Panduan Praktis Zakat, Dompet Dhuafa, Jakarta, 2012.

Didin Hafhiduddin, Zakat dalam Perekonomian Modern, Gema Insani Press, Jakarta, 2002.

Nuruddin Mhd. Ali, Zakat Sebagai Instrumen dalam Kebijakan Fiskal, PT. Raja Grafindo Persada, Jakarta, 2006.

Peraturan Pemerintah Nomor 14 tahun 2014 tentang Pelaksanaan Undang Undang Nomor 23 tahun 2011 tentang Pengelolaan Zakat.

Undang Undang Nomor 23 tahun 2011 tentang Pengelolaan Zakat.

Undang Undang Nomor 38 tahun 1999 tentang Pengelolaan Zakat.

Yusuf Qardhawi, Hukum Zakat, Pustaka Lentera Antar Nusa, Jakarta, 1987. 